\title{
KEEFEKTIFAN METODE AKROSTIK BERBANTUAN MEDIA VIDEO KEINDAHAN ALAM DALAM PEMBELAJARAN MENULIS PUISI
}

\author{
Syahruddin ${ }^{1}$ \\ Abd Rahman Rahim ${ }^{2}$ \\ Siti Suwadah Rimang ${ }^{3}$ \\ ${ }^{1}$ SD Negeri 218 Inpres Dulang Kecamatan Tanralili Kabupaten Maros Indonesia \\ 2,3 Magister Pendidikan Bahasa Indonesia, Universitas Muhammadiyah Makassar \\ Indonesia \\ syahpjj80@yahoo.co.id ${ }^{1)}$ \\ rahman@unismuh.ac.id ${ }^{2 *}$ \\ sitisuwadah@yahoo.co.id ${ }^{3}$
}

\begin{abstract}
Abstrak
Penelitian ini bertujuan untuk memeroleh, menganalisis, dan mendeskripsikan data mengenai (1) Tingkat kemampuan menulis puisi murid kelas VI SD Negeri 218 Inpres Dulang Kecamatan Tanralili Kabupaten Maros menggunakan metode akrostik berbantuan media video keindahan alam. (2) Tingkat kemampuan menulis puisi murid kelas VI SD Negeri 218 Inpres Dulang Kecamatan Tanralili Kabupaten Maros menggunakan teknik konvensional. (3) Efektif tidaknya penggunaan metode akrostik berbantuan media video keindahan alam efektif dalam pembelajaran menulis puisi murid kelas VI SD Negeri 218 Inpres Dulang Kecamatan Tanralili Kabupaten Maros. Jenis penelitian ini adalah penelitian survei dengan teknik eksperimen semu. Adapun populasi penelitian adalah seluruh kelas VI SD Negeri 218 Inpres Dulang Kecamatan Tanralili Kabupaten Maros tahun pelajaran 2020/2021. Populasi tersebut berjumlah 60 orang yang terbagi dalam dua kelas, yaitu kelas IV A dan kelas IV B dengan teknik pengambilan sampel adalah total sampling. Hasil penelitian ini menunjukkan bahwa hasil belajar menulis puisi murid kelas VI SD Negeri 218 Inpres Dulang Kecamatan Tanralili Kabupaten Maros menggunakan teknik akrostik berbantuan media video keindahan alam adalah 65,67 teknik konvensional adalah 58,33 dalam rentangan nilai 10-100. Selain itu, data pada hasil analisis keefektifan dalam uji $t$, menunjukkan nilai empiris $\left(t_{a}\right): 15,875$ sedangkan nilai teoretis $\left(t_{1}\right): 1,67$ pada taraf kpercayaan 95\%, sehingga dinyatakan bahwa nilai t empiris (hitung) lebih besar daripada nilai t teoretis (tabel) $(15,875>1,67)$ yang berarti teknik akrostik berbantuan media video keindahan alam efektif dalam meningkatkan hasil menulis puisi murid kelas VI SD Negeri 218 Inpres Dulang Kecamatan Tanralili Kabupaten Maros.
\end{abstract}

Kata Kunci: Teknik Akrostik, Video Keindahan Alam, dan Menulis Puisi

Published by:

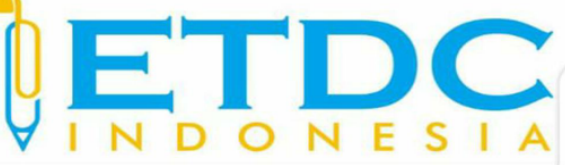

Copyright (C) 2021 The Author (s)

This article is licensed under CC BY 4.0 License

(cc) $\mathrm{BY}$ 


\section{KEEFEKTIFAN METODE AKROSTIK BERBANTUAN MEDIA VIDEO KEINDAHAN ALAM DALAM PEMBELAJARAN MENULIS PUISI}

\section{Pendahuluan}

Pembelajaran sastra khususnya puisi sangat penting bagi murid mulai sekolah dasar hingga sekolah menengah (Susanti, 2015; Jamilah et al., 2020. Hal ini karena dapat memberikan sumbangan terhadap keberhasilan pendidikan. Pengajaran sastra termasuk puisi dapat memberikan sumbangan yang maksimal terhadap pendidikan antara lain membantu meningkatkan pengetahuan budaya, mengembangkan cipta dan rasa, serta menunjang pembentukan watak (Leoni, 2021; Suhertuti, 2017; Susanti, 2015). Karena itu pembelajaran sastra menduduki peranan yang sangat penting dalam mewujudkan tujuan pendidikan.

Jika dihayati hakikatnya, puisi dapat memberi sesuatu yang sangat berarti dalam kehidupan manusia. Puisi dapat memberi nilai-nilai hidup yang bermakna. Ia dapat menyejajarkan diri dengan berbagai media lainnya untuk menyampaikan pesan-pesan kehidupan. Puisi mempunyai nilai yang sangat tinggi. Puisi dapat bernada sinis, bisa bernada simpati, antipati, dan sebagainya yang kesemuanya mengandung makna yang sangat dalam sebagai suatu alat untuk menyampaikan nilai-nilai moral yang diharapkan dapat dijadikan pilihan bagi masyarakat untuk menentukan perilaku hidup yang baik (Logita, 2018; Nurgiantoro, 2018). Begitu tinggi nilai suatu puisi dalam kehidupan manusia. Seseorang yang menutup telinga terhadap puisi akan terpencil dari suatu dunia yang penuh dengan harta kekayaan berupa pengertian manusia, pandangan perseorangan dan sensitivitas.

Aftaruddin (2010) bahwa antara puisi dan hidup tidak ada jarak yang menceraikan. Tidak ada puisi tanpa kehidupan. Masalah puisi adalah masalah hidup dan kehidupan. Puisi mengalir dalam hidup, bergerak dalam hidup dan membuka, mengembang, bersama keakuan kita lahir batin. Hidup manusia adalah manifestasi puitis. Puisi adalah bahagian dari kehidupan manusia itu sendiri. Tanpa puisi manusia tak dapat hidup." Hakikat tersebut, tampaknya disadari atau tidak, terekspresi dari jiwa penyair. Hal ini ditandai dengan luapan perasaan yang melahirkan puisi, seperti puisi "Perasaan Seni" dan "Sukma Pujangga" menggambarkan bahwa puisi lahir sebagai letupan emosi, luapan perasaan, ekspresi jiwa yang tidak dapat dibendung yang kesemuanya ingin mengatakan sesuatu (kritik) yang sangat mendesak (Rosidi, 2012; Mustamar, 2020).

Hal ini juga secara tegas dikemukakan Ayip Rosyidi dalam puisinya: "Tentang sajak", berbunyi: pertama kepada diri sendiri/pusat degup jantung gembira berteman/hasil sebuah hasil 
terpuasi/lalu aku dan baru yang lainnya (Eddy, 2010; Rosidi, 2012). Betapa tinggi nilai suatu puisi dalam kehidupan manusia, sehingga dikatakan bahwa tanpa puisi manusia tak dapat hidup. Tentu saja pernyataan itu bukan permainan kata belaka, melainkan telah menjadi kenyataan, bahwa kehidupan manusia tanpa puisi akan mengurangi satu sistem kehidupan terutama sebagai media penyampaian nilai hidup yang bermakna. Kebenaran makna puisi tidak sekadar uraian belaka, tetapi nyata dalam kandungan puisi memberi sesuatu yang sangat luar biasa.

Berdasarkan kenyataan di atas, maka wajar jika sejak dini puisi dijadikan salah satu aspek pengajaran berbahasa mulai dari SD hingga SLTA. Namun, kenyataannya, pada pendidikan formal tersebut pengajaran puisi juga mengalami berbagai permasalahan sehingga hakikat yang diinginkan dalam pengajaran puisi juga tidak tercapai dengan baik. Banyak hasil penelitian yang menunjukkan bahwa pengajaran apresiasi puisi gagal di sekolah. Penelitian Hidayat \& Indihadi (2018) dalam laporan hasil penelitiannya menyatakan siswa kelas V SD Negeri 1 Gunungpereng belum mampu mengapresiasi puisi sehingga membutuhkan intesvensi penuyelsaian masalah. Diana \& Nasihudin (2018) dalam laporan hasil penelitiannya juga senada bahwa siswa kelas IV B MIN Margasari Kota Bandung belum mampu menulis puisi dnegan bak sehingga butuh jalan keluar yang efektif. Senada dengan itu, Abduh (2018) menyimpulkan hasil penelitiannya bahwa kemampuan menulis puisi siswa siswa SMP negeri 22 makassar masih lemah sehingga mmbutuhkan pembelajaran yang efektif sebagai jalan keluar. Masalahnya, banyak pemerhati, penggiat, dan sastrawan menganggap pengajaran apresiasi sastra termasuk puisi gagal. Mereka menganggap pengajaran apresiasi sastra di sekolah tidak kondusif, padahal tujuan pengajaran apresiasi sastra dalam kurikulum sudah cukup ideal. Pengajaran apresiasi puisi di sekolah saat ini jalan di tempat dari tingkat SD hingga SMU (Sufanti, 2013; Indriati \& Haryadi, 2014; Suryaman, 2010).

Indikasi gagalnya pengajaran apresiasi sastra di sekolah menurut Taufik Ismail adalah: 1) Kurangnya hasil karya sastra siswa; 2) Rendahnya penghargaan murid terhadap karya sastra (ini dibuktikan dengan minimnya pengetahuan murid terhadap penyair Indonesia dan hasil karyanya), dan, 3) Rendahnya minat murid dalam membaca karya sastra (puisi, cerpen, dan novel) (Al-Ma'ruf, 2012; Suwondo, 2001; Sufanti, 2013). Ada beberapa faktor yang menyebabkan kegagalan pengajaran apresiasi sastra di sekolah, antara lain hasil penelitian Taufik Ismail sebagai berikut: 1) Minimnya minat murid terhadap karya sastra (motivasi). 2) Belum bakunya metode pengajaran sastra di semua jenjang pendidikan. 3) Rendahnya minat baca murid terhadap karya sastra. 4) Kebijakan pemerintah yang terkesan menganaktirikan pengajaran sastra, dan 5) Kurangnya keterampilan guru dalam mengjarkan apresisi sastra 
(Mirnawati, 2015; Muktadir, 2014; Hendrastuti, 2013; Suyanto 2017).

Jika dilihat faktor di atas, maka ada dua faktor yang mengarah pada peran sentral guru, sebagai pembina, pembimbing, dan pengajar sastra di sekolah, yakni faktor yang kedua, (belum bakunya metode pengajaran sastra di semua jenjang pendidikan) dari faktor kelima, (kurangnya keterampilam guru dalam mengajarkan apresiasi sastra di sekolah). Kondisi kegagalan ini juga mengakibatkan karya sastra termasuk puisi tidak mendapat tempat yang baik di hati masyarakat. Jangankan mencintai dan meminati, menghargai pun tidak. Kendala yang dihadapi dalam pengajaran apresiasi puisi pada prinsipnya menyangkut seluruh komponen pengajaran, seperti kurikulum, metode, guru, bahan penunjang, dan sebagainya. Oleh karena itu, jika ingin mencari solusi pengajaran puisi, maka sistem harus diperbaiki. Untuk menuju ke arah perbaikan pengajaran sastra maka setiap komponen perlu dikaji secara mendalam melalui suatu penelitian. Salah satu aspek dalam komponen pengajaran puisi yang dianggap sangat penting adalah metode pengajaran puisi (Barnawi et al., 2019; Jamilah et al., 2020; Aminah et al., 2017). Oleh karena itu, pemberlakuan metode perlu dilakukan uji coba secara akurat sehingga dapat dijadikan bahan masukan dalam perbaikan pengajaran puisi.

Berdasarkan uraian tersebut tampak bahwa pembelajaran menulis puisi sangat penting ditingkatkan dalam lingkup pendidikan. Hal dibuktikan bahwa di lapangan menunjukkan pembelajaran menulis puisi di sekolah masih mengalami kendala dan cenderung dihindari oleh murid. Hal ini disebabkan oleh tidak adanya pemahaman nilai dan manfaat lainnya yang dapat diperoleh murid ketika menulis puisi. Selain itu, teknik yang digunakan dalam pembelajaran puisi masih kurang sehingga minat dan kompetensi murid menulis puisi juga tidak memadai.

Berdasarkan hasil pengamatan awal di sekolah, dokumentasi berupa daftar nilai di sekolah tersebut menunjukkan hasil belajar menulis puisi murid masih rendah. Secara umum di kelas VI hanya rata-rata 65 dari nilai KKM 65 dan yang telah melalui remedial. Selain itu, menurut pengakuan guru metode mengajar puisi kurang variatif dan tidak memberi gairah kepada peserta didik untuk menulis puisi. Demikian halnya motivasi belajar murid berkaitan dengan puisi menurut guru juga rendah. Hal ini dilakukan karena salah satu kendala yang terkadang ditemui oleh murid dalam menulis puisi antara lain, murid kesulitan menemukan ide, kesulitan menentukan kata-kata dalam menulis puisi, kesulitan dalam memulai menulis, kesulitan mengembangkan ide menjadi puisi karena minimnya penguasaan kosakata, dan kesulitan menulis puisi karena tidak terbiasa mengemukakan perasaan, pemikiran, imajinasinya, serta kurang mampu menghubungkan antara dunia khayal dengan dunia nyata ke dalam puisi.

Oleh karena itu, salah satu langkah yang dapat dilakukan untuk mengatasi hal tersebut, 
yaitu menerapkan teknik yang dapat membantu menciptakan ide dan gagasan, yaitu metode akrostik dengan inspirasi keindahan alam. Metode akrostik ini secara konseptual dapat memberi proses kreativitas murid dalam menulis puisi melalui panduan singkatan nama tertentu yang dijadikan dasar pengembangan imajinasi dalam larik-larik puisi yang ditulis siswa (Sari et al., 2015; Dyanti, 2018). Metode akrostik dapat membantu anak menuangkan ide dan membentuk larik imajinatif melalui akrostik. Penciptaan satu puisi dapat diwujudkan melalui kegiatan analisis akrostik. Untuk mengatasi permasalahan yang dirumuskan di atas, maka suatu metode yang dipandang efektif dapat mengembangkan kreativitas murid dalam pembelajaran menulis puisi adalah metode akrostik. Secara operasional metode akrostik dapat membantu murid dalam mengembangkan tahapan penulisan puisi melalui kegiatan yang dimulai dengan pembuatan akrostik dari sebuah kegiatan inspirasi obejek tertentu. Hal ini yang membantu menuangan ide bagi siswa (Putra, 2013; Sari et al., 2015). Setelah itu, berdasarkan rangkaian kata tertentu dari akrostik dibuatlah larik-larik puisi yang puitis yang bertautan dengan ide. Hal inilah yang membantu mengatasi kesulitan murid dalam menulis puisi. Keberhasilan murid menulis puisi dengan bantuan metode akrostik dapat dilihat pada kemampuan menentukan ide puisi yang diinspirasi oleh sesuatu baik orang benda atau kondisi yang menjadi penting dibuat puisi. Selain itu dilihat keindahan dan keutuhan larik-larik yang dibangun, serta keutuhan makna puisi yang dibuat berdasarkan akrostik.

Berdasarkan uraian di atas, maka masalah yang dibahas dalm penelitian ini adalah sebagai berikut.

1. Bagaimanakah tingkat kemampuan menulis puisi murid kelas VI SD Negeri 218 Inpres Dulang Kecamatan Tanralili Kabupaten Maros menggunakan metode akrostik berbantuan media video keindahan alam?

2. Bagaimanakah tingkat kemampuan menulis puisi murid kelas VI SD Negeri 218 Inpres Dulang Kecamatan Tanralili Kabupaten Maros menggunakan teknik konvensional?

3. Apakah penggunaan metode akrostik berbantuan media video keindahan alam efektif dalam pembelajaran menulis puisi murid kelas VI SD Negeri 218 Inpres Dulang Kecamatan Tanralili Kabupaten Maros?

\section{Metode Penelitian}

Penelitian ini didesain sebagai penelitian kuantitatif, yang berupaya mengujicobakan metode akrostik berbantuan media video keindahan alam dalam menulis puisi di sekolah dasar. Penelitian eksprimen ini dilakukan pada satu kelas eksprimen dan satu kelas kontrol. Pada kelas 
eksprimen diberikan pembelajaran metode akrostik berbantuan media video keindahan alam dan kelas kontrol menggunakan metode konvensional. Lalu keduanya diberi tugas menulis puisi. Penelitian ini dilakukan di SD Negeri 218 Inpres Dulang Kecamatan Tanralili Kabupaten Maros, Provinsi Sulawesi Selatan. Subjek dalam penelitian ini adalah seluruh murid kelas VI SD Negeri 218 Inpres Dulang Kecamatan Tanralili Kabupaten Maros tahun pelajaran 2020/2021 berjumlah 60 orang.

Data dalam penelitian ini adalah data kuantitaif berupa angka-angka skala. Data tersebut berupa hasil belajar menulis puisi siswa baik menggunakan metode akrostik berbantuan video, maupun konvensional. Teknik pengumpulan data dalam penelitian ini menggunaka teknik tes. Teknik tes tersebut berupa tes membuat puisi. Adapun prosedur pngumpulan data adalah murid sampel diberikan pembelajaran menulis puisi melalui metode akrostik berbantuan media video keindahan alam bagi kelas eksperimen dan pembelajaran menulis puisi melalui teknik konvensional bagi kelas kontrol, lalu kedua sampel tersebut diberi tes menulis puisi yang sama.

Untuk mengetahui efektif-tidaknya pembelajaran menulis puisi melalui metode akrostik berbantuan media video keindahan alam, tentu saja harus diujicobakan dalam penerapan di kelas. Eksprimen yang dilakukan terhadap strategi ini yaitu, membandingkan hasil belajar menulis murid kelompkeksperimen dan kelompok kontrol. Hasil yang diperoleh oleh kedua kelas dibandingkan dangan menggunakan perhitungan statistik inferensial dengan perbedaan dua rata-rata menggunakan analisis uji korelasi dengan bantuan aplikasi SPSS versi 25.

\section{Hasil dan Pembahasan}

\subsection{Hasil Penelitian}

Adapun data yang dianalisis adalah hasil murid kelompok eksperimen (X) dan hasil tes menulis puisi murid kelompok kontrol (Y). Hasil analisis data tersebut terbagi dalam beberapa macam, yaitu skor kemampuan menulis puisi teknik akrostik berbantuan media video keindahan alam, hasil pembelajaran menulis pusi menggunakan metode konvensional, dan data perbandingan atau hasil uji " $\mathrm{t}$ " dari kedua data tersebut, serta pengujian hipotesis. Untuk lebih jelasnya diuraikan sebagai berikut.

\section{Tingkat hasil belajar menulis puisi menggunakan teknik akrostik berbantuan media}

\section{video keindahan alam}

Data tingkat hasil belajar menulis puisi murid kelas VI SD Negeri 218 Inpres Dulang Kecamatan Tanralili Kabupaten Maros menggunakan teknik akrostik berbantuan media video keindahan alam dapat dilihat pada tabel 1 berikut. 
Tabel 1. Tabel frekuensi hasil belajar menulis puisi murid kelas VI SD Negeri 218 Inpres Dulang Kecamatan Tanralili Kabupaten Maros menggunakan teknik akrostik berbantuan media video keindahan alam.

\begin{tabular}{cccc}
\hline NO & NILAI & F & N X F \\
\hline 1 & 100 & 0 & 0 \\
2 & 90 & 0 & 0 \\
3 & 80 & 4 & 320 \\
4 & 70 & 11 & 770 \\
5 & 60 & 13 & 780 \\
6 & 50 & 2 & 100 \\
7 & 40 & 0 & 0 \\
8 & 30 & 0 & 0 \\
9 & 20 & 0 & 0 \\
10 & 10 & 0 & 0 \\
& JUMLAH & 30 & 1970 \\
\hline
\end{tabular}

Sumber: hasil olah data penelitian

Berdasarkan hasil analisis data di atas dapat diketahui:

$$
\begin{aligned}
& \mathrm{N}=30 \\
& \mathrm{FN}=1970
\end{aligned}
$$

Dengan demikian skor rata-rata yaitu:

$$
\begin{array}{ll}
\text { Rerata } & : \text { FN/N } \\
& : 1970 / 30 \\
& : 65,67
\end{array}
$$

Jadi, rata-rata nilai hasil belajar menulis puisi murid Kelas VI SD Negeri 218 Inpres Dulang Kecamatan Tanralili Kabupaten Maros menggunakan teknik akrostik berbantuan media video keindahan alam adalah 65,67 dalam rentangan nilai 10-100. Selain itu, berdasarkan hasil analisis data mentah terlihat bahwa skor perolehan tertinggi adalah 80 dari skor maksimun 100 sebanyak dua orang, Jumlah seluruh skor seluruh murid yaitu 1970, sehingga rata-rata skor perolehan murid adalah 65,67.

Berdasarkan kategorisasi data, maka dapat dinyatakan bahwa hasil belajar puisi murid Kelas VI SD Negeri 218 Inpres Dulang Kecamatan Tanralili Kabupaten Maros menggunakan teknik akrostik berbantuan media video keindahan alam berada pada kategori sedang.

\section{Tingkat hasil belajar menulis puisi menggunakan teknik konvensional}

Data tingkat hasil belajar menulis puisi murid kelas VI SD Negeri 218 Inpres Dulang Kecamatan Tanralili Kabupaten Maros menggunakan Teknik konvensional dapat dilihat pada Tabel 2 berikut. 
Tabel 2. Tabel frekuensi hasil belajar menulis puisi murid Kelas VI SD Negeri 218 Inpres Dulang Kecamatan Tanralili Kabupaten Maros menggunakan teknik konvensional.

\begin{tabular}{cccc}
\hline NO & NILAI & F & N X F \\
\hline 1 & 100 & 0 & 0 \\
2 & 90 & 0 & 0 \\
3 & 80 & 0 & 0 \\
4 & 70 & 4 & 280 \\
5 & 60 & 18 & 1080 \\
6 & 50 & 7 & 350 \\
7 & 40 & 1 & 40 \\
8 & 30 & 0 & 0 \\
9 & 20 & 0 & 0 \\
10 & 10 & 0 & 0 \\
& JUMLAH & 31 & 1750 \\
\hline
\end{tabular}

Sumber: hasil olah data penelitian

Berdasarkan hasil analisis data di atas dapat diketahui:

$\mathrm{N}=\quad 30$

$\mathrm{FN}=\quad 1750$

Dengan demikian skor rata-rata yaitu:

$\begin{aligned} \text { Rerata } & : \text { FN/N } \\ & : 1750 / 30 \\ & : 58,33\end{aligned}$

Jadi, rata-rata nilai hasil belajar menulis puisi murid kelas Kelas VI SD Negeri 218 Inpres Dulang Kecamatan Tanralili Kabupaten Maros menggunakan teknik konvensional adalah 58,33 dalam rentangan nilai 10-100. Selain itu, berdasarkan hasil analisis data mentah terlihat bahwa skor perolehan tertinggi adalah 70 dari skor maksimun 100 sebanyak satu orang. Sedangkan skor terendah adalah 42 yang diperoleh oleh satu orang, Jumlah skor seluruh murid yaitu 1770, sehingga rata-rata skor perolehan murid adalah 57,1 .

Berdasarkan kategorisasi data depdikbud, maka dapat dinyatakan bahwa hasil belajar puisi murid Kelas VI SD Negeri 218 Inpres Dulang Kecamatan Tanralili Kabupaten Maros menggunakan teknik konvensional berada pada kategori sedang.

3. Keefektifan teknik akrostik berbantuan media video keindahan alam dalam Menulis Puisi Murid Kelas VI SD Negeri 218 Inpres Dulang Kecamatan Tanralili Kabupaten Maros (Analisis Uji $t$ )

Untuk menentukan keefektifan teknik akrostik berbantuan media video keindahan alam dalam pembelajaran menulis puisi murid Kelas VI SD Negeri 218 Inpres Dulang Kecamatan Tanralili Kabupaten Maros maka data dari kelompok ekperimen dan kelompok 
kontrol dianalisis dengan menggunakan analisis sebagai berikut. Selanjutnya dianalisis dengan langkah sebagai berikut.

$$
\begin{array}{ll}
\text { Mx } & : \mathrm{X} / \mathrm{n} 1 \\
\mathrm{Mx} & : 2011 / 30=: 67,03 \\
\text { My } & : \mathrm{Y} / \mathrm{n} 1 \\
\text { My } & : 1707 / 30=: 56,90 \\
\mathrm{SSx} & : \sum \mathrm{x}^{2}-\left(\sum \mathrm{x}^{2}\right) / \mathrm{n} 1 \\
\mathrm{SSx} & : 136401-134804=1596,967 \\
\text { SSy } & : \sum \mathrm{y}^{2}-\left(\sum \mathrm{y}^{2}\right) / \mathrm{n} 1 \\
\text { SSy } & : 98371-97128,3=1242,7
\end{array}
$$

Selanjutnya, hasil analisis dengan menggunakan rumus uji $\mathrm{t}$, diperoleh nilai $\mathrm{t}=$ 15,87463 . Secara deskriptif teknik ini dapat dikemukakan bahwa data kedua kelompok variabel diringkas sebagai berikut. Hasil analisis data menunjukkan:

$\begin{array}{ll}\mathrm{X} & : 66,33 \\ \mathrm{Y} & : 57,10 \\ \mathrm{SSx} & : 1596,967 \\ \mathrm{SSy} & : 1242,7 \\ \mathrm{t}_{\mathrm{a}} & : 15,875 \\ \mathrm{t}_{\mathrm{t}} & : 1,645\end{array}$

\section{Pengujian Hipotesis}

Berdasarkan hasil pengolahan data yang disajikan di atas, selanjutnya dilakukan pengujian hipotesis. Dari bahwa hasil analisis data diperoleh nilai " $t$ " empiris (hitung) sama dengan 15,875 sedangkan nilai teoretis pada taraf signifikan 0,05 dengan drajat bebas ( $\mathrm{db}$ ) sama dengan 58, ditemukan nilai tabel sebesar 1,67. Hal ini menunjukkan bahwa nilai $\mathrm{t}$ empiris/hitung lebih besar daripada nilai t teoretis (tabel) $(15,875>1,67)$. Oleh karena itu, berdasarkan kriteria pengujian hipotesis yang telah dirumuskan yaitu apabila nilai empiris lebih besar daripada nilai teoretis, maka hipotesis nol ditolak. Konsekwensinya hipotesis alternatif berbunyi: Teknik akrostik berbantuan media video keindahan alam efektif meningkatkan hasil belajar menulis puisi murid Kelas VI SD Negeri 218 Inpres Dulang Kecamatan Tanralili Kabupaten Maros". diterima. Dengan demikian, hipotesis nol yang berbunyi: Teknik akrostik berbantuan media video keindahan alam tidak efektif meningkatkan hasil belajar menulis puisi kelas VI SD Negeri 218 Inpres Dulang Kecamatan Tanralili Kabupaten Maros ditolak. Oleh karen itu, dapat dikemukakan bahwa teknik akrostik berbantuan media video keindahan alam efektif meningkatkan hasil belajar 
menulis puisi murid kelas VI SD Negeri 218 Inpres Dulang Kecamatan Tanralili Kabupaten Maros pada taraf kepercayaan 95\%.

\subsection{Pembahasan}

Berdasarkan dari data dalam penelitian ini, dapat dijelaskan bahwa hasil belajar menulis puisi murid kelas VI SD Negeri 218 Inpres Dulang Kecamatan Tanralili Kabupaten Maros menggunakan teknik akrostik berbantuan media video keindahan alam adalah rata-rata 65,57 dalam rentangan nilai 10-100. Jika dikaitkan dengan kriteria ketuntasan minimal (KKM) kelas VI SD Negeri 218 Inpres Dulang Kecamatan Tanralili Kabupaten Maros aspek menulis puisi adalah pada aspek menulis puisi adalah 65,00 maka dapat dinyatakan bahwa hasil belajar menulis puisi murid kelas VI SD Negeri 218 Inpres Dulang Kecamatan Tanralili Kabupaten Maros menggunakan teknik akrostik berbantuan media video keindahan alam tuntas. Jika dikaitkan dengan kategorisasi, nilai rata-rata maka hasil belajar tersebut berada pada kategori sedang. Selain itu, data penelitian dapat dijelaskan bahwa tingkat hasil belajar menulis puisi murid kelas VI SD Negeri 218 Inpres Dulang Kecamatan Tanralili Kabupaten Maros menggunakan teknik konvensional adalah 58,33 dalam rentangan nilai 10-100. Jika dikaitkan dengan kriteria ketuntasan minimal (KKM) kelas VI SD Negeri 218 Inpres Dulang Kecamatan Tanralili Kabupaten Maros aspek menulis puisi adalah 58,33 maka dapat dinyatakan bahwa tingkat hasil belajar menulis puisi murid kelas Jika dikaitkan dengan kriteria ketuntasan minimal (KKM) kelas kelas VI SD Negeri 218 Inpres Dulang Kecamatan Tanralili Kabupaten Maros aspek menulis puisi menggunakan teknik konvensionla belum tuntas. Jika dikaitkan dengan kategorisasi, nilai rata-rata maka hasil belajar tersebut berada pada kategori sedang.

Sementara itu, data pada hasil analisis keefektifan dalam uji t, menunjukkan nilai empiris/hitung (ta): 15,875 sedangkan nilai teoretis/tabel (tt): 1,67 pada taraf kepercayaan 95\%, sehingga dinyatakan bahwa nilai $\mathrm{t}$ empiris lebih besar daripada nilai t teoretis (tabel) $(15,675>1,67)$ yang berarti teknik akrostik berbantuan media video keindahan alam efektif dalam meningkatkan hasil menulis puisi kelas VI SD Negeri 218 Inpres Dulang Kecamatan Tanralili Kabupaten Maros. Berdasarkan hasil penelitian ini dapat dipahami bahwa salah satu alternatif mengefektifkan pembelajaran menulis puisi di sekolah dalas adalah menggunakan teknik akrostik berbantuan media video keindahan alam. Hal ini telah dibuktikan dengan ujicoba pada murid kelas kelas VI SD Negeri 218 Inpres Dulang Kecamatan Tanralili Kabupaten Maros yang menunjukkan efektif.

Pembelajaran menulis puisi yang selama ini dianggap sulit bagi murid dapat dilatihkan dengan menggunakan teknik akrostik berbantuan media video keindahan alam. Selain hasil penelitian terdapat beberapa keunggulan antara lain dalam pemanfaatan teknik akrostik 
berbantuan media video keindahan alam adalah menarik minat murid karena dilakukan secara kontennstual dan dapat dilakukan dengan lintas mata pelajaran. Hasil penelitian ini sesuai dengan konsep yang dikemukakan oleh Sayuti (2010) bahwa kekuatan dalam menciptakan puisi terletak pada penghayatan jiwa seorang penulisnya. Oleh karena itu, pembelajaran menulis puisi diarahkan pada upaya melakukan perenungan teradap masalah atau topik yang akan ditulis dalam bentuk puisi. Pandangan ini sejalan dengan Zahra (2019) bahwa puisi lahir dari penjiwaan sesuatu. Oleh karena itu, pembelajaran menulis puisi hendaknya didorong untuk menggunakan mengolaan jiwa dalam mengeksplor rasa dalam puisi melalui objek dengan panduan akrostik. Selain itu, pandangan lain mengenai menulis puisi dikemukakan oleh Iskandar (2011) bahwa bentuk paling muda melatih murid dalam menulis puisi adalah penghayatan terhadap apa yang akan ditulisnya. Akan tetapi, tentu harus dilakukan secara sunggung-sungguh melalaui panduan yang dapat menjembatani imajinasi siswa.

\section{Kesimpulan}

Berdasarkan hasil dan pembahasan penelitian dapat disimpulkan beberapa hal sebagai berikut:

a. Tingkat hasil belajar menulis puisi murid kelas VI SD Negeri 218 Inpres Dulang Kecamatan Tanralili Kabupaten Maros menggunakan teknik akrostik berbantuan media video keindahan alam masih kategori sedang. Hal ini terlihat pada rata-rata nilai hasil belajar menulis puisi murid menggunakan teknik akrostik berbantuan media video keindahan alam adalah 65,67 dalam rentangan nilai 10-10, meskipun telah dianggap telah tuntas berdasarkan KKM 65,00.

b. Tingkat hasil belajar menulis puisi murid kelas VI SD Negeri 218 Inpres Dulang Kecamatan Tanralili Kabupaten Maros menggunakan teknik konvensional masih kategori sedang. Hal ini terlihat pada rata-rata nilai hasil belajar menulis puisi murid menggunakan teknik tkonvensional adalah 56,33dalam rentangan nilai 10-10 dan dianggap belum tuntas berdasarkan KKM 65,00

c. Teknik akrostik berbantuan media video keindahan alam efektif dalam meningkatkan hasil menulis puisi murid kelas kelas VI SD Negeri 218 Inpres Dulang Kecamatan Tanralili Kabupaten Maros. Hal ini terlihat pada hasil pengujian hipotesis nilai " $t$ " empiris (hitung) sama dengan 15,875 sedangkan nilai teoretis pada taraf signifikan 0,05 dengan derajat bebas ( $\mathrm{db}$ ) sama dengan 58, ditemukan nilai tabel sebesar 1,67. Hal ini terlihat pada nilai $t$ empiris lebih besar daripada nilai t teoretis (tabel) $(15,75>1,67)$. 


\section{DAFTAR PUSTAKA}

Abduh, N. K. (2018). Pemanfaatan Teknik Akrostik untuk Meningkatkan Kemampuan Menulis Puisi Siswa Kelas VIII SMP. RETORIKA: Jurnal Bahasa, Sastra, dan Pengajarannya, 11(1), 40-47.

Al-Ma'ruf, A. I. (2012). Pendidikan Sastra Berorientasi pada Kompetensi Bersastra: Mencari Format Pembelajaran Sastra yang Inovatif.

Aftaruddin, P. (2010). Pengantar Apresiasi Puisi. Bandung: Angkasa

Aminah, S., Umar, S., \& Usman, A. (2017). Pengembangan Media Audiovisual Dalam Pembelajaran Bahasa Indonesia Untuk Keterampilan Menulis Puisi. Jurnal Pendidikan dan Pembelajaran Khatulistiwa, 6(1).

Barnawi, B., Pratama, F. A., \& Al-Ghozali, M. I. (2019). Application of a Contextual Approach in Indonesian Language Learning to Improve the Ability to Write Poetry. Action Research Journal Indonesia (ARJI), 1(2), 75-86.

Diana, I., \& Nasihudin, N. (2018). Penerapan Teknik Akrostik Untuk Meningkatkan Keterampilan Menulis Puisi Siswa Madrasah Ibtidaiyah. Al-Aulad: Journal of Islamic Primary Education, 1(2).

Dyanti, E. P. (2018). Keefektifan Teknik Akrostik dan Teknik Kata Berantai dalam Pembelajaran Menulis Teks Puisi dengan Media Video Destinasi Pariwisatapada Siswa Kelas X SMA Negeri 12 Semarang. Jurnal Pendidikan Bahasa dan Sastra Indonesia, 7(1), 19-26.

Hendrastuti, R. (2013). Sastra Terjemahan Sebagai Bahan penunjang Pengajaran Sastra. Jurnal Jakarta: Balai Bahasa.

Hidayat, G. T., \& Indihadi, D. (2018). Teknik akrostik dalam penulisan puisi. Pedadidaktika: Jurnal Ilmiah Pendidikan Guru Sekolah Dasar, 5(2), 103-109.

Indriati, D. A., \& Haryadi, H. (2014). Peningkatan Apresiasi Puisi dalam Pembelajaran Puisi dengan Media Musik di SMA Negeri 11 Yogyakarta. LingTera, 1(2), 156-167.

Iskandar, K. (2011). Munulis Puisi Anak-anak. Solo: Bentang Pustaka

Jamilah, N., Mulawarman, W. G., \& Hudiyono, Y. (2020). Pengembangan Bahan Ajar Interaktif 'POST'dalam Pembelajaran Apresiasi Puisi untuk Siswa Kelas X SMA. Diglosia: Jurnal Kajian Bahasa, Sastra, dan Pengajarannya, 3(1), 14-23.

Leoni, T. D. (2021). Pembelajaran Apresiasi Sastra Sebagai Pendekatan Untuk Penguatan Karakter Dan Mental Anak Dalam Menghadapi Situasi Covid-19. Bahasa, Sastra, Dan Pembelajarannya Dalam Masa Pandemi Covid-19, 83.

Logita, E. (2018). ANALISIS DALAM PUISI 'HUJAN BULAN JUNI'KARYA SAPARDI DJOKO DAMONO. Wacana Didaktika, 10(1), 38-48.

Mirnawati, M. (2015). Tinjauan terhadap Problematika Pembelajaran Sastra Indonesia pada 
Pendidikan Formal. AKSARA: Jurnal Bahasa dan Sastra, 16(1).

Muktadir, A. (2014). Model pembelajaran kreatif dan produktif untuk meningkatkan kualitas pembelajaran bahasa indonesia (pembelajaran apresiasi sastra) di pgsd fkip unib. PGSD Jurnal Ilmiah Pendidikan Guru Sekolah Dasar, 7(13), 143-152.

Mustamar, S. (2020). Menjelajah Genealogi Puisi Indonesia Dari Masa Balai Pustaka Sampai Era Digital. UNEJ e-Proceeding, 179-193.

Nurgiantoro, B. (2018). Sastra anak: pengantar pemahaman dunia anak. UGM PRESS.

Putra, B. A. P. (2013). Penggunaan Teknik Akrostik Kompi 9 (K-9) Untuk Meningkatkan Keterampilan Menulis Cerita Pendek Pada Siswa Kelas X-9 SMA Negeri 3 Malang Tahun Pelajaran 2012/201. Jurnal. Nosi, 1 .

Rosidi, A. (2012). Puisi Indonesia modern: sebuah pengantar. Dunia Pustaka Jaya.

Sari, D. K., Fuad, M., \& Munaris, M. (2015). Peningkatan Keterampilan Menulis Puisi Melalui Teknik Akrostik Pada Siswa Kelas X.J-SIMBOL (Bahasa, Sastra, dan Pembelajarannya), 3(2).

Sayuti, A. (2010). Proses Menciptakan Puisi. Jakarta: Insan press

Sufanti, M. (2013). Pembelajaran bahasa indonesia berbasis teks: belajar dari ohio amerika serikat. In Makalah disajikan dalam Seminar Nasional: Teks Sebagai Media Pembelajaran Bahasa Indonesia dalam menyonsong Kurikulum.

Suhertuti, S. (2017). Persepsi Guru Bahasa Indonesia Terhadap Materi Sastra Pada Kurikulum Tingkat Satuan Pendidikan Dan Kurikulum 2013. AKSIS: Jurnal Pendidikan Bahasa dan Sastra Indonesia, 1(2), 170-188.

Suryaman, M. (2010). Pendidikan karakter melalui pembelajaran sastra. Jurnal Cakrawala Pendidikan, 1(3).

Susanti, R. D. (2015). Pembelajaran Apresisasi Sastra di Sekolah Dasar. ELEMENTARY: Islamic Teacher Journal, 3(1).

Suwondo, T. (2001). Ihwal Pengajaran Sastra di Sekolah Dasar. Jakarta: Pusat Bahasa Departemen Pendidikan Nasional.

Suyanto, S. (2017). PENGAJARAN SASTRA DI SEKOLAH MENENGAH POTRET BURAM NASIB SASTRA KITA. BELAJAR BAHASA: Jurnal Ilmiah Program Studi Pendidikan Bahasa dan Sastra Indonesia, 2(2).

Zahra, S. (2019). Mari Menulis Puisi. Surabaya: Pustaka Ilmu 